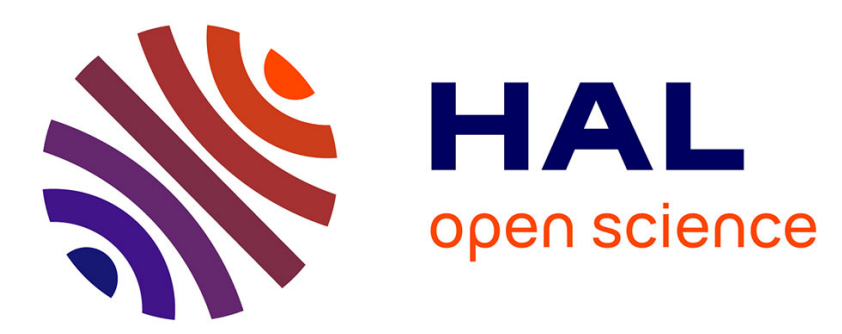

\title{
Mapping Contours of Pakistan-US Foreign Policies in the Trump Era: Narratives and Counter-Narratives
}

\author{
Muhammad Nadeem Mirza, Taimur Shamil
}

\section{To cite this version:}

Muhammad Nadeem Mirza, Taimur Shamil. Mapping Contours of Pakistan-US Foreign Policies in the Trump Era: Narratives and Counter-Narratives. Strategic Studies, 2020, 40 (3), pp.22-41. halshs02966446

\section{HAL Id: halshs-02966446 \\ https://shs.hal.science/halshs-02966446}

Submitted on 23 Oct 2020

HAL is a multi-disciplinary open access archive for the deposit and dissemination of scientific research documents, whether they are published or not. The documents may come from teaching and research institutions in France or abroad, or from public or private research centers.
L'archive ouverte pluridisciplinaire HAL, est destinée au dépôt et à la diffusion de documents scientifiques de niveau recherche, publiés ou non, émanant des établissements d'enseignement et de recherche français ou étrangers, des laboratoires publics ou privés. 


\title{
Mapping Contours of Pakistan-US Foreign Policies in the Trump Era: Narratives and Counter-Narratives
}

\author{
Taimur Shamil $^{*}$ and Muhammad Nadeem Mirza ${ }^{* *}$
}

\begin{abstract}
Narratives are used by the states to create an environment in which foreign policy takes place. The US, over the years, has framed the war on terror and its relations with Pakistan in a specific way to justify its foreign policy goals. It has used coercion as well as enticements in order to force Pakistan to fulfill its foreign policy wish-list. Pakistan which has over the years been on the receiving end of these narratives has displayed unprecedented counter-narrative strategy. Applying Neoclassical Realism as a theoretical paradigm, this paper maps the continuity and change in the narrative and counter-narrative strategies of the US and Pakistan.
\end{abstract}

Keywords: President Donald Trump, US Foreign Policy, Pakistan, Narratives, Afghanistan, Peace Process, Foreign Policy, Decision Making.

\section{Introduction}

Official and semi-official statements and policy decisions shape the political environment and impact the process through which states and nations interact with each other. The narratives have the power to sway public opinion and frame a debate around an issue that changes dynamics of politics among states and nations. Communication has changed power dynamics in the twenty-first century since it is vital to comprehend and approach the international politics. With the advent of media and social media, the public discourse and political narratives have a larger impact on how the governments chalk out their foreign policy. The new media environment, too,

\footnotetext{
* The author is PhD Scholar, School of Politics and International Relations, Quaid-iAzam University (QAU), Islamabad.

** The author is a faculty member, School of Politics and International Relations, Quaid-i-Azam University (QAU), Islamabad.
} 
have changed the way communication takes place between states. It has also changed the way diplomacy works internationally. ${ }^{1}$

Manuel Castells' work Communication Power, explores how media technologies enable change in the network patterns and impact the way public and states process and utilise narratives for their political and social gain. ${ }^{2}$ His main work is to elaborate how big powers use narratives to achieve their goals in the international arena. ${ }^{3}$ For instance, how the US administration used the narratives before the Iraq war to justify its intervention. The war in Afghanistan with its continued narrative is another similar case.

Though spanning over about seventy years, two occasions were significant for Pak-US relations. First, when the US provided support to the Mujahedeen in the Afghan-Soviet war and second, America's 'War on Terror.' These two wars were significant to both Pakistan and the US. Islamabad cooperated with Washington for its own interests. However, the mechanics of cooperation were different. What goes behind the wars that the US and Pakistan have fought, are the narratives projected by both the states to justify their foreign policy decisions at home and abroad.

This paper analyses how the Trump administration has employed narratives in its dealing with Pakistan on key issues. The article also maps Pakistan's strategy to counter the American narrative.

\section{Domestic-Systemic Linkage and Neoclassical Realism}

Applying neoclassical realist theory of International Relations, this paper elucidates how the US has interacted with Pakistan. It also explores the options and narrative Pakistan has employed to answer the US back. Neoclassical realism takes into account not just the way states interact with each other at the systemic level but also the domestic level intervening variables that determines the way states act in the international politics. The

\footnotetext{
${ }^{1}$ Tom Fletcher, Naked Diplomacy: Power and Statecraft in the Digital Age (William Collins, 2016).

${ }^{2}$ Manuel Castells, Communication Power (Oxford University Press, 2011). Also see Manuel Castells, "Communication, Power and Counter-Power in the Network Society," International Journal of Communication 1, no. 1 (February 8, 2007).

${ }^{3}$ Castells, Communication Power.
} 
intervening variables range from leaders' perception, strategic culture, statesociety relations and the domestic institutions.

Domestic intervening variables vary in their nature and influence foreign policy decisions and decision-making process. For instance domestic pressure in response to the attacks on the Twin Towers made the US invade Afghanistan. ${ }^{4}$ Public sentiment and the public opinion played great role in forming and legitimising the US decision to invade Afghanistan. Similarly, its institutional capabilities and domestic resources played the role for the US to take the decision to invade Afghanistan.

At the system and domestic levels, the situation for the US has since changed a lot. The focus is less on continuing the war in Afghanistan and more on reducing its forces there. This change in behaviour has many systemic and domestic explanations in the Neo-classical Realist Theory that particularly deals with the domestic variables in the foreign policy decision making.

While the US as a great power has had its own way of following its interests, ${ }^{5}$ Pakistan, too, has pursued its goals albeit carefully. As the Innenpolitikers - the ones who believe that domestic interest groups have stakes and say in foreign policy - are of the view that the most important element for any state before making the foreign policy decision is to understand and determine its position in the international system. ${ }^{6}$ The place in the system defines as well as limits the policy options domestically. However, neo-classical realists are of the view that Innenpolitik can better elucidate the foreign policy choices during high-stakes external challenges. ${ }^{7}$

The US war in Afghanistan' which has entered in its nineteenth year, is a war that forces Pakistan and the US to collaborate. The collaboration was

\footnotetext{
${ }^{4}$ Ken Booth and Tim Dunne, eds., Worlds in Collision: Terror and the Future of Global Order (Palgrave Macmillan, 2002).

${ }^{5}$ John J. Mearsheimer, Great Delusion: Liberal Dreams and International Realities (Yale University Press, 2018). Also see Michael Beckley, Unrivaled: Why America Will Remain the World's Sole Superpower (Cornell University Press, 2018).

${ }^{6}$ Gideon Rose, "Neoclassical Realism and Theories of Foreign Policy," World Politics 51, no. 01 (1998): 144-72.

${ }^{7}$ Ibid. Also see Norrin M. Ripsman, Jeffrey W. Taliaferro and Steven E. Lobell, Neoclassical Realist Theory of International Politics (Oxford, New York: Oxford University Press, 2016).
} 
important because both saw each other's cooperation in Afghanistan as an important step towards achievement of the foreign policy and security goals. However, in this collaboration, there also exists a permanent rift on the strategy to address Afghan conundrum. ${ }^{8}$

This paper explores how a great power-cum-hegemon like the US and a small power, like Pakistan ${ }^{9}$ communicate and use narratives in order to pursue and achieve their foreign policy goals. The narratives in this relationship have also been used as a method of bargaining. This paper maps the continuity and change in the US foreign policy towards Pakistan in the light of the statements given by President Trump and the response from the Pakistani leadership.

\section{Onset of Trump Administration's South Asia Strategy}

Pakistan was portrayed and projected in a specific way throughout the US war in Afghanistan - from an ally to a friend and then to a "frenemy."10 On many occasions, during the presidency of Bush and Obama, Pakistan was portrayed as a part of the problem but still an important country to work with. This consistent collaboration and negative framing has affected Pakistan's image as well as its relations with the US. It is important to note that President Obama never visited Pakistan in his two tenures in office. ${ }^{11}$ That speaks about Obama administration's approach towards the alliance and relations with

\footnotetext{
${ }^{8}$ Shereena Qazi, "US invested in a failed strategy in Afghanistan," Al Jazeera, February 1, 2018, https://www.aljazeera.com/news/2018/01/invested-failedstrategy-afghanistan-180131081126954.html. The cost of this war has been huge for the US as well as for Pakistan. Sarah Al Mukhtar, Rod Norland, "What Did the US Get for \$2 Trillion in Afghanistan?," New York Times, December 9, 2019, https://www.nytimes.com/interactive/2019/12/09/world/middleeast/afghanistanwar-cost.html

${ }^{9}$ Farhan Hanif Siddiqi, "Pakistan and Singapore as Small Powers: Comparative Thematic Evaluation and Policy Imperatives," African and Asian Studies 13, no. 1-2 (May 2015): 187-204, https://doi.org/10.1163/15692108-12341291.

${ }^{10}$ Shuja Nawaz, The Battle for Pakistan: The Bitter US Friendship and a Tough Neighbourhood (Liberty Publishing, 2019). Also see Sumit Ganguly, “The U S and Pakistan, Best of Frenemies,” Wall Street Journal, May 3, 2011, sec. Bookshelf, http://online.wsj.com/article/SB10001424052748704569404576298670356934488.html.

${ }^{11}$ Mohammad Shoaib Adil, "Why Obama Won't Visit Pakistan," Foreign Policy, April 10, 2015, https://foreignpolicy.com/2015/04/10/why-obama-wont-visitpakistan/.
} 
Pakistan: the US most important ally in Afghanistan. Nonetheless, the 2011 Osama Bin Laden and Salala incidents severely damaged the already "transactional relations"12 of Pakistan and the US.

In this backdrop, the Trump administration came up with its strategy towards Afghanistan and South Asia ${ }^{13}$ which had declared to keep Pakistan in the loop. President Trump from the very outset of his electoral campaign, vouched for the idea of withdrawing troops from Afghanistan. In his campaign, he reasserted that the US troops should be brought back home and more should be spent on the American people instead of spending on the costly wars overseas with no apparent end in sight, referring to wars in Afghanistan and Syria. ${ }^{14}$ As the neoclassical realists note, the perception of leaders matters the most in the foreign policy response to a systemic stimulus. ${ }^{15}$ In his election campaign, Trump's image as a leader was, and still is, of a leader who takes into account the cost and benefit - a leader with a diverse background of business, real estate and media. He also loathes several decisions taken by the Obama administration. ${ }^{16}$ Therefore, for Trump, the most important issue has been to wind up the costly and longest American wars oversea. ${ }^{17}$ In doing so, the Trump administration seemed to be musing with the idea of keeping India as an ally and a counter weight to China. ${ }^{18}$ Trump while announcing his South Asia strategy also mentioned about giving larger role to India. ${ }^{19}$ This did not come along well

${ }^{12}$ This term is used by former Secretary of State Hillary Clinton in his book. Hillary Rodham Clinton, Hard Choices (Simon and Schuster, 2014).

${ }^{13}$ Donald Trump, "Remarks by President Trump on the Strategy in Afghanistan and South Asia," The White House, August 21, 2017.

${ }^{14}$ Courtney Kube and Carol E. Lee, "Trump Wants to Pull All US Troops out of Afghanistan by 2020 Election," NBC News, August 3, 2019,

https://www.nbcnews.com/news/military/trump-wants-pull-all-troops-outafghanistan-2020-election-n1038651.

${ }^{15}$ Ripsman, Taliaferro and Lobell, Neoclassical Realist Theory of International Politics.

16 Juliet Eilperin and Darla Cameron, "How Trump Is Rolling Back Obama's Legacy,” Washington Post, January 20, 2018.

${ }^{17}$ Tanisha M. Fazal and Sarah Kreps, "The United States Perpetual War in Afghanistan," Foreign Affairs, August 20, 2018.

${ }^{18}$ Robert D. Blackwill and Ashley J. Tellis, "The India Dividend: New Delhi Remains Washington's Best Hope in Asia,” Foreign Affairs 98 (October 2019). Also see Kaura Vinay, “India-US Relations: From Distant Partners to an Alliance," Parameters 48, no. 3 (Autumn 2018): 37-46.

${ }^{19}$ Vinay Kaura, "US-Pakistan Relations in the Trump Era: Resetting the Terms of Engagement in Afghanistan," ORF Occasional Paper, no. 128 (December 2017). 
with the Pakistan authorities who have been collaborating with the US for almost two decades and bore the brunt of the war in Afghanistan. ${ }^{20}$ The apprehensions and displeasure were conveyed from Islamabad on the new strategy. $^{21}$

\section{US 'Framing' of Pakistan in 2017}

The year 2017 started off with an expected tough US stance vis-à-vis Pakistan. $^{22}$ The misunderstandings had taken deep roots already in the Obama administration. The Trump administration, at first, thought of continuing with the already existing foreign policy templates in Washington regarding Pakistan. Initially, the reports in the media quoted the American officials that the US would toughen its stance on Pakistan in order to achieve the results in Afghanistan. It was also reported that the US might also expand its drone strikes in Pakistan which had been an issue of concern for both the state and nation of Pakistan. ${ }^{23}$ In a weekly briefing, Nafees Zakaria, Pakistan's Foreign Office Spokesperson was quoted saying that the drone strikes violate Pakistan's sovereignty and Pakistan attaches importance to its relations with the US. ${ }^{24}$ The statement was, in diplomatic words, a message from Pakistan that the drone strikes would not be welcomed although Pakistan wants amicable relations with the US.

The year 2017 also saw the speedy development on Indo-US strategic partnership that 'framed' Pakistan, once again, in the terrorists supporting countries list. The White House statement titled, United States and India: Prosperity through Partnership stated that "the leaders called on Pakistan to ensure that its territory is not used to launch terrorist attacks on other countries. They further called on Pakistan to expeditiously bring to justice the perpetrators of the 26/11 Mumbai, Pathankot and other cross-border

\footnotetext{
${ }^{20}$ Trump, "Remarks by President Trump on the Strategy in Afghanistan and South Asia."

${ }^{21}$ Pamela Constable, “Trump's New Afghanistan Policy Has Pakistan Angry and Alarmed," Washington Post, August 29, 2017, sec., Asia \& Pacific,

https://www.washingtonpost.com/world/asia_pacific/trumps-new-afghanistanpolicy-has-pakistan-angry-and-alarmed/2017/08/29/40e2de88-8cb9-11e7-9c536a169beb0953_story.html.

${ }^{22}$ Reuters, "US Likely to Toughen Its Policy on Pakistan," Dawn, June 21, 2017.

${ }^{23}$ Reuters.

${ }^{24}$ Naveed Siddiqui, "Drone Strikes Violate Pakistan's Sovereignty: FO,” Dawn, June 22, 2017.
} 
terrorist attacks perpetrated by Pakistan-based groups."25 The Pakistani authorities expressed their concern on the statement saying that "the statement aggravates the already tense situation." ${ }^{26}$ Prime Minister Imran Khan, who, much like the US President Trump, believes in using technology for policy statements, took to social media, Twitter and said in a tweet that, "Trump-Modi statement has removed fig leaf of morality and justice in the US foreign policy which is now only based on arms sales and financial gains. $" 27$ The Pakistani stance on the American statements and narratives was befitting and spontaneous.

It was in the same thread of tweets that Pakistani Prime Minister told the US administration that it was not India but Pakistan that shared border with Afghanistan and the US should not allow India an interventionist role in Afghanistan. Khan, is perhaps the first Prime Minister of Pakistan who actively use social media, especially twitter, to counter the narrative being projected by the leader of a great power. Earlier, it was the US which called the shots and 'framed' Pakistan the way it liked in statements as well as on social media. Pakistan's way of countering it was through electronic media's talk shows and interviews given by the leadership.

The year 2017 saw the start of Pakistan's counter-narrative strategy and contestation of the narrative projected by the US vis-à-vis Pakistan. The same tweets, considered to be the policy statements of PM Khan, also categorically cautioned the Trump administration that their strategy in Afghanistan was bound to fail if the US continued to pursue it. This proactive way of narrative contestation was unprecedented in the Pakistan government and statecraft. The changing regional and global dynamics and more strategic options available to Pakistan changed Pakistan's perspective on narratives as well, countering them was now important. To convey this message in other times would have taken few regular official meetings between the two states. However, the use of the media ecology and social media saved the time and day for Pakistan.

\footnotetext{
25 "United States and India: Prosperity Through Partnership," The White House, June 26, 2017, https://www.whitehouse.gov/briefings-statements/united-statesindia-prosperity-partnership/.

${ }^{26}$ Syed Irfan Raza and Baqir Sajjad Syed, "Trump-Modi Nexus Worries Pakistan," Dawn, June 29, 2017.

${ }^{27}$ Imran Khan, “@ImranKhanPTI, 1:34 PM,”Twitter, June 29, 2017, https://twitter.com/imrankhanpti/status/880343733207695360.
} 


\section{Building Pressure on Pakistan}

Trump's policy of building pressure on Pakistan continued in the same year. In July 2017, the American Senator, John McCain, visited Afghanistan and, while talking to the gathering, said that Pakistan ought to change its behaviour or else the US, as a nation, will change its behavior towards Pakistan. ${ }^{28}$ The statements of influential Senator McCain were taken seriously in Pakistan. The Foreign Office, in Pakistan, responded to the statement with much concern that the Taliban and the Haqqani network operated from Afghanistan. ${ }^{29}$ This was to reassert that Pakistan was not looking for any blame game either from the American or the Afghanistan side. The mood from Washington did not look pleasant as far as the statements were concerned and Trump administration, too, seemingly pursued the tough stance on Pakistan, much like Obama administration. The repeated blame game from the American side and the Pakistan's consistent reply that it was Afghanistan where the problem lies, not in Pakistan, reached its height when the Pentagon blocked Pakistan's Coalition Support Fund (CSF). ${ }^{30}$ The support fund was provided to Pakistan for its assistance to the American forces in Afghanistan.

The major hint of the shift that was going to take place between Pakistan and the US took place when Commander, Resolute Support Mission (RSM) and United States Forces in Afghanistan, Gen John W. Nicholson met Pakistan's Chief of Army Staff (COAS) General Qamar Javed Bajwa in July 2017. ${ }^{31}$ Pakistan raised the concern over the criticism that it faced from the American policy circles and Trump administration. The words, as shown in the archives, from the Pakistani side were much thought over, calculated, yet straight forward. ${ }^{32}$ The statements that followed the meeting of General Nicholson with General Bajwa were

\footnotetext{
${ }^{28}$ AFP, "McCain Calls for Support of Pakistan to Eliminate Militancy in Afghanistan,” Dawn, July 5, 2017.

${ }^{29}$ Naveed Siddiqui, "Haqqani Network Operates from Afghanistan,” Dawn, July 6, 2017.

${ }^{30}$ Lisa Ferdinando, "Pentagon Spokesman: US Wants Pakistan to Take "Decisive Action” Against Terrorism," US Department of Defence, January 8, 2018, https://www.defense.gov/Explore/News/Article/Article/1410401/pentagonspokesman-us-wants-pakistan-to-take-decisive-action-against-terrorism/.

${ }^{31}$ ISPR, 'Press Release: No PR-380/2017-ISPR,' Inter Services Public Relations Pakistan, July 24, 2017, https://www.ispr.gov.pk/press-release-detail.php?id=4137. ${ }^{32}$ ISPR.
} 
calculated. Meanwhile, occasional critical statements and comments continued from the US Congress which wanted Trump to take harder stance on Pakistan. ${ }^{33}$

The messages from the US were somewhat mix. On one hand, the US military stressed sustained ties with Pakistan, on the other hand, Trump criticised Pakistan in his first address as Commander-in-Chief of the US army at Fort Myer. ${ }^{34}$ That was yet another way of strategically using the pressure tactic to force a state that the US thought is not doing enough. The general perception that was being created by the Trump administration visà-vis Pakistan was that if the US has not been able to defeat the Taliban it was primarily because of Pakistan. The narrative was once again chalked out by the Trump administration to use it as a pressure tactic against Pakistan.

\section{Pakistan's Counter-Narrative}

Pakistan officially adopted a tit-for-tat approach on Trump administration's statements regarding Pakistan. The politicians were quoted saying that Pakistan would not become the scapegoat in the region and that the US has to take the responsibility of what has been going on in Afghanistan. ${ }^{35}$ The perception was rampant in Pakistan that the US wanted to blame Pakistan for the troubles that it faced because of its failed strategy in Afghanistan. The strategic community as well as the political community shared the same sentiments in Islamabad.

While Trump took a hard stance on Pakistan, it also seemed that the officials in Washington were not taken on board as far as the statements regarding Pakistan were concerned. The US military officials as well as the then ambassador of the US did the firefighting through statements regarding Pakistan in which Pakistan's importance in the fight against terror was asserted. The US Ambassador to Pakistan, David Hale met Foreign Minister Khawaja Asif to explain Trump's "statement on the US policy review on

\footnotetext{
${ }^{33}$ Anwar Iqbal, 'Bills Suggesting Curbs on US Assistance to Pakistan Okayed,' Dawn, July 15, 2017.

${ }^{34}$ Donald Trump, President Trump Addresses the Nation at Fort Myer, Virginia (Virginia: US Department of State, 2017), https://www.youtube.com/watch?v=wOQ8su1Cxrc\&feature=emb_title.

35 "We Must Reject Being Made Scapegoats for the US Policy Failures," Dawn, August 22, 2017.
} 
South Asia and Afghanistan," a Pakistani foreign office press release quoted. ${ }^{36}$ The firefighting of the US diplomats looked futile in the face of the statements that were to be followed later in 2017 and 2018.

Pakistan Army's media wing, Inter Services Public Relations (ISPR), quoted General Bajwa, in his meeting with the US ambassador at Army's General Head Quarters (GHQ) that Pakistan was looking for trust with the US not financial gains. ${ }^{37}$ The mood in Islamabad was rapidly changing, in accordance with the kind of narrative that was being projected by the US vis-à-vis Pakistan. Pakistani authorities seemingly chalked out a counter narrative, contrary to what Trump administration was portraying regarding Pakistan. The alternative narrative was that Pakistan would follow its own national security goals. Islamabad also asserted that Washington needed to revise its strategy regarding Afghanistan and keep Pakistan in the loop. The idea was to convey this message and counter the narrative that was damaging Pakistan's image.

This war of narratives took another turn when Chinese Foreign Minister, Wang Yi, while visiting Pakistan, met the Foreign Secretary Tehmina Janjua and assured her of Chinese support to Pakistan. ${ }^{38} \mathrm{He}$ additionally stated that China appreciated Pakistan's fight against terrorism. ${ }^{39}$ The timely visit of Chinese Foreign Minister proved to be a blessing for Pakistan which until then was under criticism from the American side.

The 24th August meeting of Pakistan's National Security Committee discussed the Trump administration's South Asia Strategy. "The Committee out rightly rejected the specific allegations and insinuations made against

\footnotetext{
${ }^{36}$ Press Release: "The US Ambassador David Hale Paid a Courtesy Call on the Foreign Minister this Afternoon," Ministry of Foreign Affairs, Government of Pakistan, PR No: 280/2017, August 22, 2017, http://mofa.gov.pk/?sfid=10663\&_sft_category=pressreleases\&post_date $=22082017+26082017$.

${ }^{37}$ ISPR, Press Release, "Mr. David Hale, US Ambassador to Pakistan called on Chief of Army Staff (COAS) General Qamar Javed Bajwa at GHQ today. The Ambassador Briefed COAS About New US Policy," Inter-Services Public Relations, Government of Pakistan, No PR-432/2017-ISPR, August 23, 2017, https://www.ispr.gov.pk/press-release-archive.php?cat=army\&dt=2017-08-23.

${ }^{38}$ Naveed Siddiqui, “After Trump's Afghan Policy Statement, China Reaffirms Support to Pakistan," Dawn, August 22, 2017.

39 Ibid.
} 
Pakistan. It was observed that scapegoating Pakistan will not help in stabilising Afghanistan."40 Pakistan's official response to Trump's South Asia strategy was thought to be befitting. The same month, Pakistan's Foreign Minister embarked on his three-state visit: China, Russia, and Turkey. ${ }^{41}$ The idea was to discuss America's new South Asia strategy with other countries and chalk out a response to it. It was also a signal and a message from Pakistan about the new opportunities that were emerging for Pakistan in the region, and to show Washington that the regional countries too, not just the US, had stakes in Afghanistan. In short, Pakistan was conveying the message that it had other options that were more reliable and less demanding than the US.

The narrative against Pakistan built momentum. The top US commander in a statement said that the US was aware of the presence of Taliban commanders in the Pakistani cities of Quetta and Peshawar. ${ }^{42}$ The US commanders were pressurising Pakistan in its recent bid to win over regional support, especially with China and Russia. A planned visit of the US top South Asia diplomat, Alice Wells, to Pakistan was postponed. It was reported that the visit was postponed on the request of the Pakistani government. The displeasure by the Pakistan government was evident. ${ }^{4}$

The matter of President Trump's remarks at Fort Myer, were taken up by the Senate and later at the National Assembly of Pakistan. A resolution was passed which unanimously condemned the remarks by the Trump administration. ${ }^{44}$ The resolution also rejected the claims by the US General

\footnotetext{
${ }^{40}$ Press Release: "The National Security Committee in its meeting on August 24, 2017 discussed the Trump Administration's South Asia Strategy", Ministry of Foreign affairs, Government of Pakistan, August 24, 2017, http://mofa.gov.pk/thenational-security-committee-in-its-meeting-on-24-august-2017-discussed-thetrump-administrations-south-asia-strategy/.

41 "FM gets directions from Sharif before embarking on three-nation visit," Dawn, August 27, 2017.

42 "US aware of Afghan Taliban's presence in Peshawar and Quetta: Gen John Nicholson," Dawn, August 27, 2017.

${ }^{43}$ Naveed Siddiqui, 'US official's visit to Islamabad postponed on Pakistan's request: US Embassy', Dawn, August 27, 2017.

44 "The National Assembly of Pakistan Unanimously rejects the unacceptable targeting of Pakistan by US President Donald Trump," Resolution 177, National Assembly of Pakistan, August 30, 2017, http://www.na.gov.pk/uploads/documents/questions/1504096058_807.pdf
} 
Nicholson. ${ }^{45}$ The mater was also taken up by various national and international media outlets. America's strategy of arm twisting was rejected by Pakistani state and its people. It also refused to buy the narrative that the US wanted to project regarding Pakistan. These measures taken by Pakistan were the counter-narrative approach to the US policy of framing Pakistan as a country that was supporting the Taliban and was not doing enough in the war against terror.

Optics play a crucial role in international relations and so does the narrative that surrounds them. The joint press conference by visiting Pakistani Foreign Minister Khwaja Asif and the Chinese top diplomat Wang Yi was one such example in September 2017. ${ }^{46}$ It was made clear that both countries shared a common strategy regarding Afghanistan and that Pakistan was strengthening its relations with China. It was also an effort to mobilise the regional narrative on counter-terrorism and to counter the prevailing and dominant US narrative on Afghanistan.

Pakistan-US relations saw some improvement when Foreign Minister Khawaja Asif visited Washington and met his counterpart, Secretary of State, Tillerson. The meeting brought better understanding. However, Khwaja Asif was quoted saying that Pakistan was concerned about India's role in the new US strategy. ${ }^{47}$ This was unacceptable to Pakistan which had over the decades been concerned and skeptic about Indian role in the regional matters, especially Afghanistan. The Asif-Tillerson meeting also brought in a breakthrough on Afghanistan. Pakistani Foreign Minister was quoted by Voice of America that Pakistan would play an important role in starting a quadrilateral dialogue on ending Afghanistan's war. ${ }^{48}$ The quadrilateral group included Pakistan, China, the US, and Afghanistan.

Pakistan-US relations, in the last few months of 2017 saw a breakthrough when a Canadian couple, kidnapped in 2012, was freed from

\footnotetext{
45 Ibid.

46 “Some Countries' Need to Give Pakistan Credit For Its Counterterrorism Role: China," Dawn, September 8, 2017.

${ }^{47}$ APP, "Pakistan Genuinely Concerned About India's Role in New US Strategy:

Khawaja Asif," Dawn, October 6, 2017.

${ }^{48}$ Anwar Iqbal, "Pakistan Atempts to Restart Afghan Peace Process," Dawn, October 10, 2017.
} 
terrorists' custody in Pakistan. ${ }^{49}$ President Trump praised the cooperation with Pakistan and lauded Pakistan's effort in rescuing the couple. Later in October, same year, Muscat moot on Afghanistan took place in which the representatives of all four countries were present. The moot was a breakthrough on the stalled Afghan peace talks. "Foreign Secretary Tehmina Janjua, US Assistant Secretary of State Alice Wells and Afghan Deputy Foreign Minister Hekmat Khalil Karzai led their respective delegations." 50

The US developed a quite successful narrative about Pakistan's role in convincing Taliban to talk to Washington about ending the war in Afghanistan. However, the issue was quite puzzling for Pakistan which had earlier twice tried for the peace talks. The Murree Peace Talks, arranged by Pakistan, were called off because of unexpected news of the death of Taliban leader, Mullah Omar. Many in Islamabad considered it a deliberate act to offset peace process. Islamabad once again endeavoured to bring the two sides on negotiation table but this time killing of the new Taliban leader Mullah Mansour, by a drone attack, while he was entering from Iran to Pakistan, once again brought the talks to a standstill. Under these circumstances, restoring peace talks was a risky business for Pakistan. The players in the Afghan game were unpredictable, so was the game itself. Pakistan, since the killing of Mullah Mansour, responded with a counternarrative that there exists some elements in the US and in Afghanistan who do not want to see peace in the country.

In parallel, Pakistan also engaged in a narrative building about Afghan soil being used by the terrorists to launch attacks against it and started seeking assurance from the US to prevent such cross-border attacks. The masterminds of the worst terrorist attacks in Pakistan were residing in Afghanistan - allegedly getting aid from Indian intelligence agencies. On October 19, 2017, the news came that commander of the notorious terrorist group Jamaat-ul-Ahrar, Omar Khorasani — one of the most wanted terrorists involved in planning deadly attacks in Pakistan - along with other group leaders, was killed in a US drone strike. It was a big news.

\footnotetext{
49 "Canadian-American Family, Kidnapped in 2012 in Afghanistan, Recovered by Pakistan Army," Dawn, October 12, 2017.

${ }^{50}$ Anwar Iqbal, Iftikhar A. Khan, "Muscat Moot Breaks the Ice on Stalled Afghan Talks," Dawn, October 17, 2017.
} 
Media portrayed his killing as a reciprocal gesture by the US to the rescuing of Canadian couple by the Pakistan forces.

Later in October, the US Secretary of State Rex Tillerson visited Islamabad. Once again, it was noted that there was no change in the US rhetoric regarding Pakistan. The daily Dawn quoted, "Tillerson in Pakistan with a tough message on "safe havens." ${ }^{\text {.51 }}$ The 'safe havens' mantra was thought to be deliberately used by the US to pressurise Pakistan to 'do more' than what Pakistan was already doing. The last two episodes of trust building were a hiccup in the strained relations. Pakistan reciprocated in the similar manner to the Trump administration. The Senate of Pakistan took up the matter and criticised the approach that the US and NATO had adopted to address terrorism. ${ }^{52}$ Pakistan's Foreign Minister, Khawaja Asif told the Senate that Pakistan had made it clear to the US that its strategy in Afghanistan was not working and that it had to rethink about addressing the Afghan issue. He said, "Their failures over the past 16 years [since the war in Afghanistan started] is before them."

The year 2017 ended with an unprecedented statement by the spokesperson of Pakistan army. In his media briefing on December 28, he said, "It is time Afghanistan and the US to do more for Pakistan," it was widely quoted by all the leading Pakistani newspapers. ${ }^{54}$

\section{Tweeting Lies and Deceit: Abysmal Start of 2018}

Trump's first tweet of 2018 read, "The United States has foolishly given Pakistan more than 33 billion dollars in aid over the last 15 years, and they have given us nothing but lies and deceit, thinking of our leaders as fools. They give safe haven to the terrorists we hunt in Afghanistan, with little help. No more!"55

\footnotetext{
${ }^{51}$ AP, "Tillerson in Pakistan with a Tough Message on 'Safe Havens," Dawn, October 24, 2017.

52 "The Senate Standing Committee on Defence," October 26, 2017, http://www.senate.gov.pk/en/news_content.php?id=2594

53 "Pakistan Says US Should Accept Defeat in Afghanistan, Agrees to Assistance on Equal Terms," Dawn, October 25, 2017.

54 "Time for Afghanistan and US to Do More for Pakistan: DG ISPR," Dawn, December 28, 2017.

${ }^{55}$ Donald J. Trump, @ realDonaldTrump, Twitter, 5:12 PM, January 1, 2018, https://twitter.com/realdonaldtrump/status/947802588174577664?lang=en
} 
This was an attempt to internationally humiliate Pakistan and to coerce it into cooperation. The tweet was a strategic move loaded with political rhetoric with a clear message. Pakistani response was of restraint. There was no rapid reply of the tweet. However, the National Security Committee "noted its deep disappointment with some of the recent statements articulated by the American leadership." frenzy over the tweet and deep anguish lurked in the power corridors in Islamabad, yet no fiery official statement came out. Pakistan's response was calculated in the form of a press release quoted by its Press Information Department. $^{57}$

Trump's tweet started building a coercive discourse vis-à-vis Pakistan. By early 2018, the US started reasserting India's stance on Pakistan and brought up the issue of arrest of Hafiz Saeed. The US Department of State's Spokesperson, Heather Nauert, said that the US regarded Saeed as a terrorist and part of a terrorist organisation. ${ }^{58}$ Pakistan reaffirmed that it would take care of Hafiz Saeed issue. ${ }^{59}$ The US, while having tried the pressure from the Afghanistan side, now tried to pressurise Pakistan from the issues related to Pakistan's eastern border, India. It was another way of framing Pakistan as a country supporting the terror infrastructure.

The attacks in Kabul and elsewhere in Afghanistan ${ }^{60}$ continued which undermined the US efforts. "There would be no tolerance for those who offer sanctuary to the terrorist groups," 61 the US embassy in Afghanistan quoted Tillerson after a deadly attack in January. ${ }^{62}$ While tensions continued and war of words became intense, the Pakistani Foreign Office remained

\footnotetext{
${ }^{56}$ Press Release, "PR No. 7 Meeting of the National Security Committee Islamabad: 2nd January, 2018," Press Information Department, Ministry of Information and Broadcasting, Government of Pakistan, http://pid.gov.pk/site/press_detail/7361. ${ }^{57}$ Ibid.

${ }^{58}$ Heather Nauert, Department Press Briefing, Office of the Spokesperson, US Department of the State, January 18, 2018, https://www.state.gov/briefings/department-press-briefing-january-18-2018/ 59 "PM Abbasi Reaffirms Plan to Seize Control of Hafiz Saeed-Run Charities," Dawn, January 23, 2018.

${ }^{60}$ Mujib Mashal and Jawad Sukhanyar, "It's a Massacre: Blast in Kabul Deepens Toll of a Long War," New York Times, January 27, 2018, sec. World, https://www.nytimes.com/2018/01/27/world/asia/afghanistan-kabul-attack.html.

${ }^{61}$ Press Releases, US Embassy in Kabul, January 27, 2018, https://af.usembassy.gov/secretary-rex-w-tillersons-statement-attack-kabul/. 62 “Trump Urges 'All Nations’ to Fight Taliban,” Dawn, January 29, 2018.
} 
engaged in back-door-diplomacy with the US. ${ }^{63}$ The months to come saw exchange of top diplomats from the US and Pakistan discussing ways to cooperate and move on with the challenges in the relations.

The 2018 was also election year in Pakistan. The new Pakistan Tehreeke-Insaf (PTI) government led by Imran Khan was vocal about the US illplanned war in Afghanistan and calling it a mistake. ${ }^{64}$ The US Secretary of State, Mike Pompeo, met Khan along with a delegation including top US General, Joseph Dunford. The meetings produced statements which talked of expectations from both sides. Shah Mahmood Qureshi, the newly appointed foreign minister, while talking to the press said that the meetings took place in cordial environment and that it could be seen in the "body language." ${ }^{65}$ He further added that Pakistan's key concerns were put in forth before the US delegation and that finger pointing will get Pakistan and the US nowhere. Qureshi, in diplomatic words, had informed the Pakistani media that Pakistan had conveyed it to the US that blame game wouldn't help improve the relations and that there was a need to stop it. Secretary Pompeo while talking to the media said that he wanted to reset the relations with Pakistan. ${ }^{66}$ While the official statements were all smiles.

Many in Pakistan were skeptical about the outcome of the talks since Pompeo and General Dunford, after spending few hours with the Pakistani leadership, were scheduled to visit India on a two-plus-two meeting that was going to ink the US-India cooperation in mutual defence. ${ }^{67}$ Dawn quoted an unknown senior Pakistani diplomat saying that the cancellation of CSF to

63 "Behind-the-Scenes Diplomacy with the US Continuing: FO," Dawn, February 24, 2018.

64 “Joining US-led War on Terror Pakistan's Biggest Mistake: PM Khan," Nation, September 23, 2019.

${ }^{65}$ Anwar Iqbal, Inamullah Khattak, "PM Imran Khan, US Secretary of State

Pompeo discussed Bilateral Ties During Meeting at PM House," Dawn, September $5,2018$.

${ }^{66}$ Phil Stewart, "Pompeo Upbeat On 'Reset' with Pakistan After Meeting New PM Khan," Reuters, September 5, 2018, https://www.reuters.com/article/us-pakistanusa-pompeo/pompeo-upbeat-on-reset-with-pakistan-after-meeting-new-pm-khanidUSKCN1LLOV6.

${ }^{67}$ Abhimanyu Bose, "Delhi 2+2 Dialogue Live Updates: Mike Pompeo, James Mattis Meet PM Modi," NDTV, September 6, 2018, https://www.ndtv.com/indianews/delhi-2-2-dialogue-live-updates-india-us-to-hold-high-level-talks-1912097 
Pakistan ${ }^{68}$ had underscored the future engagement. ${ }^{69}$ The US and Pakistan had differences on the strategy to fight the combatants in Afghanistan. Pakistan also had raised the issue that Pakistan would not fight anybody else's war on its own soil.

The US official visits were reciprocated by Foreign Minister Qureshi, who was in the US to attend 73rd United Nations General Assembly (UNGA). He met his American counterpart and National Security Advisor Bolton. It is noteworthy that parallel to the Pakistan-US official meetings and the consequent statements, think tanks in Washington D.C. continued to play an important role in building narrative around the Pakistan-US relationship. The narratives in these think tank based discussions gave an insight into the mood prevailing in D.C. about Pakistan. ${ }^{70}$ The end of 2018 saw another round of criticism on Pakistan by President Trump. His interview with Fox News ${ }^{71}$ and his tweets ${ }^{72}$ regarding Pakistan aggravated the circumstances for the diplomatic channels which had recovered after number of diplomatic meetings in Islamabad and Washington. The relations and mood in both capitals got strained again. Prime Minister Imran Khan

68 "Exclusive: Pentagon Cancels Aid to Pakistan Over Record on Militants," Reuters, September 2, 2018, https://www.reuters.com/article/us-usa-pakistanmilitary-exclusive/exclusive-pentagon-cancels-aid-to-pakistan-over-record-onmilitants-idUSKCN1LH3TA. Also see Ayaz Gul, "Pakistan Looks to 'Move On' Despite Row Over US Phone Call," VOA, August 28, 2018, https://www.voanews.com/south-central-asia/pakistan-looks-move-despite-rowover-us-phone-call.

${ }^{69}$ Baqir Sajjad Syed, "Pompeo Due Today in Islamabad Amid Chill in Pak-US Ties," September 5, 2018.

70 "Pathways to Change: Pakistan Policy Symposium," Wilson Center, October 18, 2018, https://www.wilsoncenter.org/event/pathways-to-change-pakistan-policysymposium

${ }^{71}$ Gregg Re, "Trump, in Exclusive Interview, Speaks on Acosta, Reveals Obama's Private Guidance on Greatest US Threat," Fox News, November 18, 2018, https://www.foxnews.com/politics/trump-in-exclusive-interview-reveals-obamasprivate-guidance-on-greatest-threat-to-the-u-s.

${ }^{72}$ President Trump Tweeted, "Of Course We Should Have Captured Osama Bin Laden Long Before We Did. I Pointed Him Out In My Book Just BEFORE the Attack on the World Trade Center. President Clinton Famously Missed his Shot. We Paid Pakistan Billions of Dollars and they Never Told Us He Was Living There. Fools!..” Donald J. Trump, @realDonalTrump, Twitter, 8:26 PM, November 19, 2018 , https://twitter.com/realDonaldTrump/status/1064540462848098304?. 
took to Twitter and called it "Trump's false assertions."73 The Trump administration was consistent in building consistent pressure on Pakistan. Any 'tweet from the blue' could now aggravate the situation. There was skepticism in Islamabad whether these tweets are an outcome of a well thought over plan or a briefing or was it random.

The year 2018, which saw several ups and downs, ended with Trump's letter to Khan. In the letter, Trump asked for Pakistan's cooperation and assistance in bringing Taliban to the negotiation table with the US. ${ }^{74}$ This letter kick-started a pro-active approach of Trump administration. The US Special Representative to Afghanistan, Zalmay Khalilzad soon started frequent visits to Pakistan and Afghanistan. ${ }^{75}$ In response to his visits, Prime Minister Khan ensured Pakistan's "abiding interest" in attaining peace in Afghanistan. ${ }^{76}$

While the mood in both capitals changed positively but the war of narratives continued. The Washington Post quoted Imran Khan saying, "We are not your hired gun anymore." "77 While the US placed Pakistan on the special watch list of religious freedom. ${ }^{78}$ The Foreign Office rebuffed the

${ }^{73}$ PM Khan Tweeted, “Trump's False Assertions Add Insult to the Injury Pak has Suffered in US WoT in Terms of Lives Lost and Destabilised and Economic Costs. He Needs to be Informed About Historical Facts. Pak has Suffered Enough Fighting US' War. Now We Will Do What is Best For Our People \& Our Interests," Imran Khan, @ImranKhanPTI, Twitter, 9:28 PM, November 19, 2018, https://twitter.com/ImranKhanPTI/status/1064556017881686021?.

${ }^{74}$ Steve Holland, "Trump Tells Pakistan Taliban Talks Help Fundamental To 'Enduring Ties,” Reuters, December 3, 2018, https://www.reuters.com/article/uspakistan-usa-afghanistan/trump-asks-pakistan-pm-for-help-with-afghan-peace-talkspakistani-minister-idUSKBN1O20QM?il=0.

75 "Ambassador Zalmay Khalilzad was Appointed by Secretary Pompeo as the US Special Representative for Afghanistan Reconciliation on September 21, 2018," Zalmay Khalilzad, US Department of State, September 21, 2018, https://www.state.gov/biographies/zalmay-khalilzad/

${ }^{76}$ Fahad Chaudhry, "PM Reiterates Pakistan's 'Abiding Interest' for Afghan Peace in Meeting with US Envoy Khalilzad,” Dawn, December 5, 2018.

${ }^{77}$ Lally Wemouth, "Pakistani Leader to the US: We're Not Your 'Hired Gun' Anymore," Washington Post, December 7, 2018, https://www.washingtonpost.com/outlook/pakistani-leader-to-the-us-were-not-yourhired-gun-anymore/2018/12/06/e138790c-f8a5-11e8-863c9e2f864d47e7_story.html.

${ }^{78}$ AFP, "US Adds Pakistan to Blacklist for Religious Freedom Violations," Dawn, December 11, 2018. 
step taken by the US State Department, calling it "politically motivated.",79 Nonetheless, in a major breakthrough Khalilzad and Taliban held a Pakistan aided meeting in the United Arab Emirates (UAE), also attended by the officials from Pakistan, the UAE and Saudi Arabia. ${ }^{80}$ The talks continued in 2019. Pakistan's entry into Financial Action Task Force's (FATF) grey list remained a bone of contention between the two. ${ }^{81}$

The visit of Prime Minister Khan to the US and his sought-after bilateral meeting with President Trump was an important highlight in Pakistan-US relations. ${ }^{82}$ Both leaders met in the Oval Office and talked to the press. The statements that came out of the talks between Khan and Trump were positively received in Washington as well as in Islamabad. Other than Afghanistan, President Trumps offered to mediate on Kashmir. ${ }^{83}$ Back in Pakistan, the ruling party called Trump's offer a diplomatic success. ${ }^{84}$

The year 2019, overall, ended up on a constructive note. There were ups and down but the meetings between both leaders brought understanding on the policy making level. The narratives, however, from the US side kept pressurising Pakistan to do more on the Afghanistan front and to force Taliban to sign the peace deal. On Dec 29, Taliban agreed for a temporary ceasefire in order to let the peace talk conclude. ${ }^{85}$

\footnotetext{
${ }^{79}$ Naveed Siddiqui, "Pakistan Rejects 'Politically Motivated' Listing as Violator of Religious Freedoms by US,” Dawn, December 12, 2019.

${ }^{80}$ Baqir Sajjad Syed, "First Pak-Aided US-Taliban Talks Held in UAE," Dawn, December 18, 2018.

${ }^{81}$ Senator A. Rehman Malik, "FATF Bombshell via USA Country Report," News International, November 12, 2019.

82 "Remarks by President Trump and Prime Minister Khan of the Islamic Republic of Pakistan Before Bilateral Meeting," Oval office, The White House, July 22, 2019, https://www.whitehouse.gov/briefings-statements/remarks-president-trump-primeminister-khan-islamic-republic-pakistan-bilateral-meeting/

${ }^{83}$ Ibid.

${ }^{84}$ Amir Wasim, "US Mediation Offer Over Kashmir Huge Diplomatic Success: PTI," Dawn, July 24, 2019.

${ }^{85}$ Kathy Gannon and Rahim Gaiez, "Taliban Council Agrees to Cease-Fire in Afghanistan," Associated Press News, December 29, 2019, https://apnews.com/caa4c5aaf88e982ed0cdb4e132b0d89c.
} 


\section{Conclusion}

Since the time of Obama adminstration, the US narrative about Pakistan has been that Pakistan has not done enough on the Afghan front. It has used coercion and enticement both. Trump administration, seemingly, has used various narratives to pressurise Pakistan. The withdrawal of the military aid and fierce statements were used against Pakistan to make it follow the American wish-list. Black listing Pakistan on religious freedom, FATF, Taliban sanctuaries, and safe havens of the Taliban commanders in Pakistan were some of the narratives that were used against Pakistan.

However, Pakistani authorities have become cautious of the American wish list vis-à-vis Afghanistan. Pakistani leaders have maintained that Pakistan does not have the leverage over the Taliban the way it did back in 1990s. Also, making it clear that Pakistan would not become the scapegoat ${ }^{86}$ in Afghanistan and that the American strategy in Afghanistan has failed. ${ }^{87}$

In terms of digital diplomacy and narrative building, Prime Minister Khan has saved the day for Pakistan, especially on Twitter. His replies to the tweets of President Trump has set a new precedent in the age of technology. That also sets the mood and counters the one-sided narrative on a range of issues; from monetary aid to safe havens and from fighting terrorism to becoming a partner in the region. The continuity of coercion through statements, as well as through actions, is likely to continue from the American side. Pakistan, on the other hand, has adopted a cautious policy while dealing with the US.

\footnotetext{
${ }^{86}$ AFP, 'Pakistan Won't Be a 'Scapegoat' in Afghan War, PM Abbasi Tells UN General Assembly,” Dawn, September 22, 2017.

${ }^{87}$ Ibid.
} 